\title{
Implikasi Kepemimpinan Yesus Bagi Pemimpin Kristen Millenial Berdasarkan Markus 10:43-45
}

\section{Yogi Darmanto \& Krido Siswanto}

Sekolah Tinggi Teologi Simpson

Email: yogijunior202@gmail.com, kridosiswanto70@gmail.com

Article History
Submit:
5 Februari 2020
Revised:
15 Mei 2020
Published:
16 Mei 2020

be like servants, and leaders must be fully dedicated in service.

Key Words: Leadership, Mark's Gospel, Millenial.

\begin{abstract}
Abstrak:
Berdiskusi mengenai kepemimpinan berarti mengemukakan tentang cara-cara atau strategi yang digunakan oleh seorang pemimpin dalam memimpin suatu organisasi. Pemimpin ialah seorang individu yang paling berpengaruh dalam suatu organisasi yang ada yang dipercayakan untuk membawa suatu organisasi tersebut kepada sebuah sasaran atau visi yang akan dicapai dalam beberapa waktu selama masa jabatan/pelayanannya. Tuhan Yesus telah menunjukan teladan-Nya dalam memimpin. Namun dalam kenyataannya, banyak pemimpin Kristen kurang memperhatikan bagaimana pola kepemimpinan yang Yesus ajarkan. Metode yang digunakan dalam karya ilmiah ini adalah studi literatur induktif Alkitab. Dalam karya ilmiah ini, penulis menemukan ada tiga hal yang ada dalam diri Yesus mengenai implikasi kepemimpinan dalam Markus 10:43-45. Diantaranya yaitu, pemimpin harus melayani bagi sesama, pemimpin harus seperti seorang hamba, dan pemimpin harus berdedikasi penuh dalam pelayanan.
\end{abstract}

Kata Kunci: Kepemimpinan, Injil Markus, Milenial.

\section{Pendahuluan}

Kepemimpinan secara etimologi berasal dari kata "Leadership" yang berasal dari akar kata "leader". Pimpinan (leader) adalah orang yang memimpin, "Dalam pengertian lain istilah kepemimpinan berasal dari kata dasar "pimpin" yang artinya bimbing atau tuntunan. Dari "pimpin" lahirlah kata kerja "me- 
mimpin" yang artinya membimbing dan menuntun Sugono (2014). Berbicara mengenai kepemimpinan berarti berbicara mengenai cara-cara atau strategi yang digunakan oleh seorang pemimpin dalam memimpin suatu organisasi tersebut Katarina dan Siswanto (2018). Mengacu kepada beberapa pengertian di atas, kepemimpinan dapat diartikan sebagai sebuah organisasi ataupun instansi yang didalamnya terdapat manajemen-manajemen yang dipimpin oleh seorang pemimpin dengan menggunakan pola-pola tertentu. Sedangkan pemimpin ialah seorang individu yang paling berpengaruh dalam suatu organisasi yang ada yang dipercayakan untuk membawa suatu organisasi tersebut kepada sebuah sasaran yang akan dicapai.

Dalam bukunya, Nelson (2002) menerangkan bahwa pemimpin adalah orang yang mampu melihat dan mengemukan visi, melakukan perubahan dengan cara menyelaraskan orang-orang dengan sumber daya, dan mengatur banyak orang dengan suatu sistem untuk memperoleh sasaran yang akan dicapai, ditambahkan oleh Maxwell (1995) yang berpendapat bahwa, kepemimpinan adalah pengaruh, tidak lebih dan tidak kurang. Seorang pemimpin harus mampu menghasilkan satu pengaruh yang signifikan. Dalam hal ini, kepemimpinan dan pemimpin memiliki perbedaan dari segi makna tetapi merupakan kedua sisi yang tidak bisa terpisahkan. Tomatala (2002) kembali menegaskan bahwa kepemimpinan memberi tempat kepada pemimpin, orang yang dipimpin dan situasi dalam lingkungan kerja suatu organisasi. Artinya ialah setidaknya ada tiga hal yang harus ada dalam sebuah kepemimpinan.

Bagi pemimpin-pemimpin Kristen masa kini, Tuhan Yesus sendiri sudah memberikan banyak sumbangsih terhadap konsep kepemimpinan, tentu salah satunya ialah pemimpin sebagai hamba. Kata hamba dalam bagian ini berasal dari bahasa Yunani yaitu Doulos (Doulos), yang dalam bagian ini memiliki arti ialah pelayan (servant) artinya adalah hamba yang terikat atau tidak berkuasa atas dirinya. Dengan demikian, secara otomatis seorang hamba ialah seorang yang melayani. Pemimpin bukan saja dituntut harus mampu memipin anggotaanggotanya atau bawahannya saja tetapi juga harus bisa melayani orang-orang di bawahnya dengan baik.

Menurut Plueddemann (2009) pemimpin dalam keperbedaan budaya pada dasarnya ialah sama meskipun tampak berbeda. Harming dan Katarina (2019) menjelaskan mengenai keadaan kehidupan sosial Injil Markus, Situasi sosial dalam Injil Markus adalah sebuah keadaan yang memiliki kompleksitas 
sehingga persoalan yang terjadi pun begitu kompleks. Injil Markus menjelaskan bagaimana kepemimpinan Yesus yang melayani. Meskipun disisi lain Markus juga menggunakan istilah Anak Allah untuk menyebut Tuhan Yesus (Markus 1:1). Injil Markus adalah Injil kedua di bagian Perjanjian Baru dalam Alkitab. Injil Markus digolongkan kedalam Injil Sinoptis bersama-sama Injil Matius dan Injil Lukas. Penulis Kitab ini menurut tradisi adalah Yohanes Markus, ditulis kurang lebih tahun 115, Injil Markus berisi tentang satu kisah sejarah yang menyajikan tentang diri dan karya Yesus Kristus Tenney (2013). Dua tema besar dalam Injil Markus adalah tentang kerahasiaan Yesus sebagai Mesias dan Yesus sebagai Hamba yang melayani. Kemudian, apakah hubungan Injil Markus dengan kepemimpinan Yesus? Tema inti dari kitab Injil Markus ialah membicarakan Yesus sebagai Hamba. Simanjuntak (1976) menjelaskan bahwa "kiasan yang terdapat dalam 10:45 menunjukan kepada garis ajaran pokok hidup Tuhan Yesus yang diberikan sebagai korban, adalah satu tebusan bagi banyak orang dan darah perjanjian."

Markus 10:43-45, menceriterakan tentang permintaan kedua muridnya yang bernama Yakobus dan Yohanes mengenai perkenanan untuk duduk dalam kemuliaan bersama Tuhan Yesus atau disebelah kanan-Nya kelak. Yesus menyatakan bahwa Yohanes dan Yakobus tidak tidak tau dengan apa yang sedang ditanyakan, mengenai itu, Yesus tidak berhak untuk memberikannya, itu hanya akan diberikan hanya kepada itu disediakan. Dalam ceritera selanjutnya, ada kaitannya dengan kepemimpinan Tuhan Yesus, yang Tuhan Yesus katakan bukan memerintah dengan tangan besi, bukan memerintah, melainkan melayani orang-orang yang seharusnya melayaniya. Pengajaran Yesus tentang kepemimpinan juga merupakan sebuah ungkapan dalam hal spiritual para pemimpin masa kini. Yesus tidak menekankan orang-orang untuk menjadi pemimpin, melainkan menekankan pemimpin untuk melayani yang lainnya.

Di abad ke-20 ini, tentu ada begitu banyak para pemimpin muda terkhusus pemimpin muda yang mengatasnamakan kekristenan baik yang memimpin organisasi secara umum maupun dalam organisasi Kristen. Menurut Pigai (n.d.), dewasa ini kepemimpinan sedang mengalami suatu perubahan arah yang sangat mengejutkan bagi dunia kepemimpinan, baik dalam dunia kepemimpinan sekuler atau umum maupun dalam kepemimpinan Kristen. Tentu sebagai pemimpin muda Kristen harus memimpin secara benar sesuai dengan teladan Tuhan Yesus. Dengan demikian mau tidak mau tentu apapun 
yang dipikirkan dan dilakukannya harus berdasarkan dengan sebagai-mana mestinya yang telah Yesus teladankan.

Sedangkan bagi pemimpin muda Kristen yang berada dalam bidang pelayanan, harus mampu menentukan prioritas dan memberikan teladan bagi orang-orang terkhusus jamaat Tuhan yang dilayani. Winarto (2019) menegaskan bahwa "menentukan prioritas adalah suatu keharusan agar tetap setia pada panggilan dan tetap bijaksana dalam melaksanakan tugas. Semua orang Kristen terpanggil untuk melakukan sesuatu pelayanan Kristen yang tertentu dan masing-masing harus menerima panggilannya yang khusus."Jadi, sebagai pemimpin muda Kristen, tentu prioritas dalam memimpin adalah kepemimpinan yang berkarakter Kristus. Lakukan apa yang telah Tuhan Yesus teladankan dalam masa kepemimpinan-Nya di dunia.

Rumusan masalahnya adalah apa saja implikasi kepemimpinan Yesus bagi pemimpin Kristen Milineal berdasarkan eksegese Markus 10:43-45? Tujuan penulisan ini adalah tentu untuk menjelaskan implikasi kepemimpinan Yesus bagi pemimpin Kristen Milineal berdasarkan eksegese Markus 10:43-45.

\section{Metode}

Metode yang digunakan dalam penelitian ini adalah metode penelitian studi literatur induktif Alkitab dan pendekatan tematis yaitu pertama, dengan mengumpulkan data-data dari berbagai sumber seperti buku-buku tentang kepemimpinan, artikel-artikel, jurnal, internet dan lain-lain, kedua, menambahkan perbandingkan dan mengkolaborasikan dari sumber-sumber tersebut dan ketiga, menyimpulkan hasil-hasil analisis penelitian tersebut.

Pendekatan tematis digunakan untuk memahami keteladanan kepemimpinan Yesus, kemudian melakukan sintesa dari berbagai sumber mengenai keteladanan Yesus dalam memimpin. Penulis kemudian melakukan analisis terhadap sumber-sumber yang terkait. Hasil analisis tersebut kemudian dipaparkan secara deskriptif, sehingga menjadi sebuah uraian. Hasil analisis terhadap keteladanan kepemimpinan Yesus juga dilihat perannya bagi kepemimpinan Millenial. Implikasi yang dikemukakan bersifat teoritis dan praktis, sehingga temuan dari penelitian ini dapat bermanfaat bagi pengembangan keilmuan dalam kepemimpinan Kristen dan praktik kepemimpinan Kristen. Penelitian ini di dukung oleh beberapa buku utama: Kepemimpinan Yang Dinamis, Tafsir Injil Markus, Kepemimpinan Kristen Yang Mengubahkan, Sprituality And 
Leadership Buku pendukung: Leading Across Cultures, Prinsip-prinsip Dasar Kepemimpinan dan buku-buku lainnya serta Tafsiran Matthew Hendri dengan ditambahkan beberapa artikel Jurnal.

\section{Pembahasan}

\section{Yesus Pemimpin Pelayan}

Dalam Alkitab Bahasa Indonesia Terjemahan Baru ayat 43 dituliskan demikian, "Tidaklah demikian di antara kamu. Barangsiapa ingin menjadi besar di antara kamu, hendaklah ia menjadi pelayanmu," sementara dalam Updated King James Version berbunyi demikian, "But so shall it not be among you: but whosoever will be great among you, shall be your minister". Dalam Alkitab Terjemahan Baru, kata "besar" berasal dari kata megas (megas), kata benda yang bisa diartikan "agung". Agung artinya ialah mulia atau luhur, sedangkan pelayan dalam ayat ini ialah diakonos (diakonos), adalah kata benda yang artinya "diaken/ministred/pelayan" (Sabda 5.1, n.d., s.v. Diakonos; Sugono, 2014, s.v. Agung). Sihombing (2015) menerangkan bahwa diaken dipercayakan untuk mengatasi berbagai macam permasalahan, diperjelas lagi oleh Ginting (2018) bahwa hidup dari seorang diaken harus berpadanan dengan firman Tuhan, memuji yang baik dan menegur yang salah, artinya ialah apa-pun yang dikerjakan ialah berdasarkan firman Allah. Pernyataan serupa diungkapkan oleh Hannas dan Rinawaty (2019) bahwa “dinamika kepemimpinan Kristen semestinya berbeda dengan kepemimpinan sekuler atau pada umumnya. Tuhan Yesus memanggil pemimpin Kristen yang penuh kerendahan hati dan memimpin dengan tujuan melayani." Seorang pemimpin Kristen harus setia dalam melayani, seperti apa yang Tuhan Yesus ajarkan dan teladankan.

\section{Yesus memimpin seperti seorang Hamba}

Di ayat ke 44 Alkitab versi Indonesia Terjemahan Baru menyatakan bahwa "dan barangsiapa ingin menjadi yang terkemuka di antara kamu, hendaklah ia menjadi hamba untuk semuanya." Sedangkan dalam Updated King James Version berkata "And whosoever of you will be the chiefest, shall be servant of all." Kata "terkemuka" dalam bahasa aslinya ialah protos (protos) menunjukan kata adjektif (benda) yang dalam bagian ini artinya ialah "anak sulung". Sedangkan "hamba" adalah Doulos (doulos) (Sabda 5.1, n.d., s.v. Doulos) Inggris Servant 
yang artinya pelayan-pelayan. Dalam beberapa perbandingan, makna kata sulung ialah kesayangan (Yeremia 31:20), berkuasa atas yang lebih muda (1 Samuel 20:29), menggambarkan kemuliaan kristus (Roma 8:29, Kol. 1:18), kemuliaan Jemaat (Ibrani. 12:23). Artinya untuk menjadi seorang yang sulung haruslah melayani menjadi seorang hamba. Lebih dari seorang pelayan, kepemimpinan Yesus juga memberikan teladan untuk merendahkan diri sebagai Hamba. Kata hamba dalam Bahasa Yunani adalah menggunakan kata benda tunggal dan sebagai pelaku. Henry (2011) kembali menegaskan bahwa Ia mengambil rupa seorang hamba, yang datang bukan untuk dilayani dan dinantikan, melainkan untuk melayani dan menanti untuk menyatakan kebaikanNya. Setiap orang yang ingin menjadi besar dan terkenal hendaklah menjadi seperti hamba. Yesus memberi contoh kepada murid-murid-Nya bahwa seseorang itu harus melayani bukan dilayani. Hamba kadang mendapat penyiksaan dan penderitaan, tetapi hamba yang setia akan dipercayakan kepadanya semua harta yang dimiliki tuannya. Seperti Yesus yang setia melakukan tugas BapaNya yang disurga, maka Allah menganugerahkan tahta di surga. Jika setia melakukan tugas yang diberikan Kristus maka akan bersama Dia di dalam rumahNya. Yesus mengangkat derajat hamba yang semula hanya objek penderita, milik majikan dan selalu mendapat perlakuan yang tidak baik dari majikannya menjadi subjek atau pelaku.Yesus menghargai pekerjaan hamba yang tidak kenal lelah mengerjakan pekerjaan sesuai tugas yang diberikan kepadanya. Yesus hanya membiarkan diri-Nya untuk dikenal sebagai hamba Allah.

\section{Yesus berdedikasi penuh dalam pelayanan-Nya}

Apa yang ayat 45 katakan mengenai kepemimpian Yesus? Dalam bagian ini Alkitab versi Indonesia Terjemahan Baru mengatakan bahwa "Karena Anak Manusia juga datang bukan untuk dilayani, melainkan untuk melayani dan untuk memberikan nyawa-Nya menjadi tebusan bagi banyak orang." Sementara dalam Updated King James Version berkata bahwa "For even the Son of man came not to be ministered unto, but to minister, and to give his life a ransom for many. Lebih dari semua itu, Tuhan Yesus memberikan diri sepenuhnya dalam pelayanan-Nya, termasuk nyawa-Nya. Pemimpin yang benar harus siap mengorbankan nyawanya demi pelayanannya. Dalam hal itu, ia menunjukan kasih dan keseriusannya dalam kepemimpinannya. 
Wofford (1999) menjelaskan bahwa Pemimpin yang melayani mengutamakan nilai-nilai pelayanan, perhatian terhadap kebutuhan orang lain, dan kerendahan hati, visi kepemimpinan yang melayani berasal dari nilai-nilai mereka. Visi dasar mereka ialah untuk memberikan hidup mereka untuk melayani Allah yang mereka kasihi. Gembala yang baik mengenal Domba-dombanya dan dombanya juga mengenal gembalanya. Holdaway (2001) Lebih dari pada itu ialah seorang pemimpin harus mampu menjadi teladan. Tari (2019) menjelaskan bahwa Yesus Kristus meninggalkan teladan bagi pemimpin Kristen atau Hamba Tuhan untuk diteladani. Dalam pelayanan orang percaya diharapkan menyerupai Kristus kepala dan gembala. Orang percaya patut mengupayakan keserupaan dengan Kristus sebagai kepala yang menghambat dan sebagai gembala baik. Kristus sebagai Kepala gereja dimengerti dalam arti hamba/pelayan, sesuai dengan apa yang dikatakan-Nya tentang diri-Nya sendiri: "Anak Manusia datang bukan untuk dilayani, melainkan untuk melayani dan untuk memberikan nyawa-Nya menjadi tebusan bagi banyak orang." (Mat 20:28).

Stefan Leks (2007) menegaskan kata hamba, dalam Injil Markus, mengacu kepada fungsi seorang bawahan (Mrk 12:2,4; 13:34;14:7). Seorang hamba tergantung secara hampir menyeluruh dari majikan yang dilayaninya. Namun, dalam teks ini, majikan itu bukan seorang individu melainkan seluruh komunitas Kristen. Meskipun nyawa yang akan menjadi taruhannya demi dombanya. Berhitu (2014, p. 273) menambahkan Markus memandang Yesus sebagai hamba Allah yang menyerahkan diri-Nya sebagai korban keselamatan. Injil Markus menjelaskan secara detail bahwa kedatangan Yesus bukan untuk melayani, melainkan untuk melayani dan menebus dosa manusia (Mrk 10:45). Pelayanan Yesus didasarkan atas kasih yang tiada tara, Dia telah mengorbankan nyawa-Nya demi orang-orang yang dilayani. Ciri khas yang paling utama yang ditunjukkan-Nya adalah, Ia rela mati dan berkorban demi kawanan dombaNya. Tomatala (2002) menegaskan bahwa kepemimpinan Kristen dibangun di atas dasar panggilan Allah, kasih Kristus, kebenaran dan keadilan. Artinya bukan atas kemauan sendiri secara memaksa. Maedjaja (2018) memaparkan bahwa dalam perkataan Tuhan Yesus "Akulah gembala yang baik" (Yoh. 10:14) "Baik" tidak berarti sayang atau penuh kebajikan, tetapi berarti juga sejati, tulus hati dan patut diandalkan. Tong (1991) menegaskan setelah Tuhan Yesus menyatakan cinta kasih yang begitu sempurna, barulah manusia mengenal Allah. 
Itulah bukti kasih Yesus kepada dombanya, menunjukan bahawa kasih seorang pemimpin kepada orang yang dipimpin. Pemimpin rohani adalah pemimpin yang membawa seseorang untuk semakin memahami kebenaran firman Tuhan dan oleh firman Tuhan itulah yang membuatnya mampu menghadapi semua pergumulan hidupnya bersama Tuhan" (Channing, 2002).

\section{Implikasi Bagi Pemimpin Millenial}

Pemimpin Mellenial merupakan pemimpin-pemimpin muda yang tentu hidup di era modern dan berkecimpung dengan teknologi modern. Dalam hal ini, Ronda (2016) menegaskan bahwa "salah satu pilar kepemimpinan Kristen yang efektif adalah menjadi pemimpin yang transformatif, yaitu menjadi agen perubahan." Kemudian menurutnya (2019) “transformatif artinya pemimpin harus siap membawa perubahan bagi organsiasi yang dipimpinnya jika ingin organisasi itu terus relevan dalam zamannya. Saat ini, dunia kepemimpinan telah banyak di emban oleh pemimpin millenial. Pernyataan serupa diungkapkan oleh Karrang (2020). Jika melihat keadaan kepemimpinan sekarang ini, lebih banyak dikuasai oleh para kaum milenial yang dikatakan oleh para ahli mereka adalah yang lahir sekitar tahum 1980 hingga awal tahun 2000 sebagai akhir dari kaum ini. Kepemimpinan milenial sering diartikan sebagai kepemimpinan dalam dunia modern di mana segala sesuatunya dilakukan dengan pemanfaatan dari pesatnya perkembangan teknologi. Banyak perbedaan dalam kepemimpinan milenial dengan kepemimpinan Yesus. Tidak dipungkiri bahwa banyak pemimpin milenial yang sudah tidak memperhatikan bagaimana pemimpin Kristen yang seharusnya. Dalam organisasi yang dipimpin milenial yang paling memprihatinkan adalah tidak adanya pengorbanan dari para pemimpin dan semua harus dilakukan oleh anggota biasa.

Henry (2011) memaparkan bahwa umumnya kekuasaan disalahgunakan dalam dunia ini. Kepemimpinan masa kini cenderung dalam ambisi pribadi dan organisasi, sehingga keteladanan Yesus dalam memimpin tidak menjadi prinsip dasar dalam kepemimpinan. Pemimpin seharusnya dapat mengayomi orang yang dipimpin dengan baik, melindungi, dan memberi kesejahteraan bukan memanfaatkan kekuasaan, kemewahan dan kemegahan. Dari analisis di atas, keteladanan kepemimpinan Yesus yang harus dimiliki pemimpin Kristen Millenial berdasarkan Markus 10:43-45 antara lain: 


\section{Pemimpin Yang Melayani Bagi Sesama}

Pelayanan merupakan proses pemenuhan kebutuhan melalui aktivitas orang lain secara langsung ('Pengertian Pelayanan: Apa Itu Pelayanan?', 2014, s.v. Pelayanan). Berangkat dari ayat 41 kesepuluh murid yang lain marah kepada Yakobus dan Yohenes. Mereka marah kepada Yakobus dan Yohanes karena menginginkan tempat utama. Mereka marah bukan karena sulitnya menjadi murid Kristus, tetapi karena mereka masing-masing juga berharap untuk memiliki tempat utama itu. Kemudian dilanjutkan dengan pernyataan Tuhan Yesus dalam ayat ke 42. Menurut Marianti (2013) Kepemimpinan adalah suatu seni, proses, kegiatan, bahkan kemampuan seseroang untuk mempengaruhi orang lain dalam organisasi tersebut untuk mencapai tujuan organisasi tersebut. Henry (2011) mengungkapkan bahwa memerintah rakyatnya dengan tangan besi, maksudnya, semua yang dilakukan lakukan dan kehendaki pemerintah sama sekali bukan untuk melindungi rakyat dan menyediakan kesejahteraan rakyat,, tetapi untuk berkuasa atas rakyatnya. Dalam bagian ini apa Yesus katakan mengenai kepemimpinan? Barangsiapa yang ingin menjadi besar, hendaklah ia menjadi pelayan. Seorang pemimpin yang baik akan berinisiatif melayani bukan menuntut semata-mata hanya untuk dilayani.

Bahwa hal demikian tidak dapat diakui dalam kepemimpinan Kristen. Janganlah ada di antara kamu yang berlaku demikian; mereka yang ada di bawah kekuasaanm harus menjadi seperti domba di tangan gembala, yang melindungi dan memberi mereka makan, dan menjadi pelayan bagi mereka, dan bukanlah seperti kuda yang berada di bawah perintah penunggangnya, yang mempekerjakan dan memukul mereka, dan mendapatkan untung dari pekerjaan (Hendry, 2011). Maedjaja (2018) mengungkapkan bahwa pemimpin tidak cukup hanya sayang atau penuh kebajikan, tetapi juga harus sejati, tulus hati dan patut diandalkan. Dengan demikian, dapat dikatakan bahwa seorang pemimpin ialah seorang yang rendah hati. Yeakley (2013) memaparkan bahwa kerendahan hati adalah jalan untuk bertumbuh dalam kasih karunia. Pemahaman banyak orang tentang melayani Tuhan adalah aktif dalam kegiatan rohani di lingkungan gereja, yaitu dengan mengambil bagian dalam tugas tertentu. Sesungguhnya anggapan seperti ini justru membuat mereka tidak pernah melayani Tuhan dengan benar, sebab yang terbangun adalah anggapan bahwa segala kegiatan di luar lingkungan gereja bukanlah pelayanan bagi Tuhan. Melalui kerendahan hati dalam melayani Tuhan memberikan salah satu teladan. Sikap 
hidup dalam melayani itu sangat-sangat penting. Warren (2013) menerangkan bahwa: untuk menjadi seorang pelayan dibutuhkan perubahan mental dan sikap pelayan harus lebih memikirkan orang lain lebih dari dirinya sendiri terutama dari segi perhatiannya. Brake (2014) menambahkan bahwa manusia dalam suatu masalah yang begitu besar, tidak ada seorangpun lagi yang menghiraukannya lagi, disitu Allah berkarya dalam hidupnya ketika tidak ada seorangpun yang berani menjamah manusia karena dosa, disitulah Yesus mengulurkan tangan-Nya untuk memanggil dan menjamah supaya manusia hidup dalam kekudusan. Itulah yang Tuhan Yesus kerjakan bagi umat-Nya.

Pemimpin yang baik tidak cukup hanya mampu memanajemen kepemimpinannya saja, tetapi juga harus mampu mengajar dengan baik. Sidjabat (2017) menegaskan bahwa mengajar bukanlah sesuatu yang mudah sebab harus mampu menghasilkan suatu perubahan, perubahan kepada apa? Tentu peubahan kepada yang lebih baik dan secara signifikan. Yesus juga menunjukkan betapa Ia tidak membeda-bedakan pelayanan. Ia pergi ke kotakota, dan cacat, dan yang lemah. Teladan Yesus yang diambil dari Markus 10:13-16, dikenal sebagai orang yang ramah dan terbuka untuk anak-anak (ay. 13). Lalu orang membawa anak-anak kecil kepada Yesus, supaya Ia menjamah mereka; akan tetapi murid-murid-Nya memarahi orang-orang itu. Tari (2019) Yeakley (2013) menambahkan pemipin yang berhati hamba tidak egois dan menuntut haknya, tidak menuntut untuk dilayani, tetapi melayani. Tidak ada keegoisan dalam sebuah kepemimpinan. Johanes dan Tambahani (2014) menegaskan bahwa bila bertemu seseorang yang belum mengenal Yesus, bantulah untuk memulihkan hubungannya dengan Allah melalui Kristus. Itulah yang dinamakan dengan pelayanan. Artinya ialah dalam kekristenan arti kata pelayanan ialah suatu kegiatan membantu seseorang tanpa mengharapkan imbalan. Apapun yang dilkukannya semuanya harus berdasarkan pada orientasi kepada kehendak Allah semata-mata. Bukan soal seberapa keuntungan yang akan didapatkan, melainkan seberapa besar kemampuan untuk memberikan ruang bagi orang lain untuk menemukan citra dirinya sebagai manusia yang dibimbing serta di beri peran atau kepercayaan untuk kembali berinovasi.

\section{Memimpin Seperti Seorang Hamba}

Kepemimpinan harus memberi tempat kepada pemimpin, orang yang dipimpin dan situasi dalam lingkungan kerja suatu organisasi. Tomatala (2002) 
Tidak selamanya pemimpin itu harus blak-blakan dalam berbicara, akan lebih baik secara lemah lembut namun memberi makna dan dampak yang hebat. Mensah (2005) mengatakan, Jemaat Tuhan hanya layak dipimpin seorang pelayan yang senantiasa dibarui akal budinya oleh hikmat dan Roh Allah. Selebihnya itu bukan berasal dari Roh Allah. Canada (2005) menambahkan bahwa Allah adalah kasih dan tentu yang Yesus perintahkan kepada murid-muridNya juga ialah supaya saling mengasihi seperti kasih yang telah diberikan Yesus. Sejatinya kepemimpinan dalam layaknya seorang hamba juga harus memberi peran dalam sumbangsih penemuan jati diri orang-orang yang dipimpin, seperti apa yang disampaikan oleh Tjhong (n.d.) bahwa kepemimpinan tidak mengubah orang, tetapi untuk menawarkan ruang dan kebebasan di mana perubahan dapat terjadi. Ini bukan ajakan untuk mengadopsi gaya hidup pemimpin, tetapi karunia kesempatan bagi angota-angotanya untuk menemukan dirinya sendiri. Kepemimpinan bukan mengintimidasi, memaksa, menghambakan, atau mendominasi bawahan, tidak ada otoritarianisme, penghormatan, keunggulan posisional, senioritas, hirarki, atau keuntungan yang aneh atau tertentu untuk setiap pemimpin dalam Kristen, karena "hanya" Kristus menjadi orientatornya. Jadi, dari apa yang telah dipaparkan di atas oleh Tjong sederhanya ialah seorang pemimpin harus mampu memberi peran dalam membantu anggotanya untuk menemukan jati dirinya. Demikian juga Yesus, melayani dengan penuh kasih, seperti layaknya orientasi seorang pelayan yang melayani tuannya.

Pigai (n.d.) mengutip ungkapan Peniel Maiaweng yang menjelaskan bahwa, Kata hamba diterjemahkan dari kata doulos yang berarti budak atau orang yang terikat pada orang lain (tuannya), atau orang yang tidak berkuasa atas dirinya sendiri. Terjemahan lain dari kata doulos adalah tunduk, yang berhubungan dengan ketaatan dan kepatuhan dalam pengabdian dalam buku Pemberdayaan Jemaat Menjadi Pelayan Jemaat juga dijelaskan, “Kata doulos juga seorang yang mengabdikan dirinya pada orang lain tanpa mempedulikan keinginan-keinginan pribadinya. Jadi, pengertian hamba lebih difokuskan kepada orang yang memiliki pengabdian dan terikat kepada pekerjaan yang dilaksanakannya dan mempertanggung jawabkannya kepada tuan pemiliknya. Pigai (n.d.) Inilah arti kata hamba atau budak, yaitu seseorang yang bekerja pada orang lain dan tidak berkuasa atas dirinya karena milik tuannya dan yang melaksanakan segala hal yang diperintahkan kepadanya. 


\section{Dedikasi Pelayanan Penuh}

Kristus taat sampai mati, dan demi kerajaan-Nya, karena Ia memberikan nyawa-Nya menjadi tebusan bagi banyak orang. Bukankah Ia telah mati untuk keuntungan orang-orang yang dibenarkan? Bukankah para pemimpin masa kini harus berusaha untuk hidup demikian pula? Pasande (2019) menegaskan bahwa "jika belajar dari Yesus, dalam melakukan peran, tugas dan tanggung jawab kepemimpinan, elemen dasar yang pertama yang harus dimiliki yaitu; Karakter seperti Yesus Kristus haruslah dimiliki. Tujuan Yesus datang ke dunia ini bukanlah hanya sekadar untuk menyelamatkan umat manusia. Tujuan utamanya adalah membawa manusia ke dalam kemuliaan dan menjadi serupa dengan Dia." Pasande (2019) menambahkan kembali bahwa Tuhan Yesus adalah teladan yang sempurna bagi para pemimpin kristen yang ingin menjadi rendah hati. Pengajaran-Nya yang luar biasa; Ia sendiri mengajarkan bahwa siapa yang meninggikan diri akan direndahkan, dan siapa yang merendahkan diri akan ditinggikan (Luk. 14:11). Proses pembentukan untuk menjadi serupa dengan Yesus memang tidak mudah dan tidak terjadi secara instan. Perlu kerja keras dan disiplin diri yang kuat. Tidak kalah penting, seorang yang berdedikasi penuh dalam pelayanan ialah seorang yang terus memiliki hubungan yang dekat dengan Tuhan. Demikian Winarto, (2019) memaparkan bahwa untuk menjadi pemimpin yang berhasil. Harus dimulai dari dalam diri pemimpin itu sendiri, pemimpin harus memiliki hubungan yang baik dulu dengan Tuhan baru mampu menjalankan pelayanannya dengan baik serta menghasilkan kesan yang baik. Ketika sudah memiliki hubungan yang dekat dengan Sang Penciptanya, maka tentu apapun yang dirancangkan dan dikerjakannya akan berdasarkan orientasi kepada kehendak Allah semata-mata.

\section{Kesimpulan}

Kepemimpinan adalah sistim atau manajemen-manajemen yang ada dalam sebuah organisasi yang dipimpin oleh seorang pemimpin dengan menggunakan pola-pola tertentu. Sedangkan pemimpin ialah seorang individu yang paling berpengaruh dalam suatu organisasi yang ada yang dipercayakan untuk membawa suatu organisasi tersebut kepada sebuah sasaran atau visi yang akan dicapai dalam beberapa waktu selama masa jabatan/pelayanannya. Hubungan Injil Markus dengan kepemimpinan Yesus terutama isi dari kitab 
Injil Markus yang membicarakan Yesus sebagai Hamba. Markus 10:45 adalah garis ajaran pokok hidup Tuhan Yesus. Tuhan Yesus telah menunjukan teladan-Nya dalam memimpin. Kepemimpinan Kristen semestinya berbeda dengan kepemimpinan pada umumnya. Tuhan Yesus memanggil pemimpin Kristen yang penuh kerendahan hati dan memimpin dengan tujuan melayani." Seorang pemimpin Kristen harus setia dalam melayani, seperti apa yang Tuhan Yesus ajarkan dan teladankan. Berdasarkan pembahasan di atas, implikasi kepemimpinan Yesus bagi pemimpin Kristen millenial dalam Markus 10:43-45 adalah: Pertama, pemimpin harus melayani bagi sesama. Kedua, mempimpin seperti seorang hamba. Ketiga, dedikasi pelayanan penuh dalam memimpin.

\section{Daftar Rujukan}

Berhitu, R. J. (2014). Peran Gembala Jemaat Terhadap Pengembangan Pelayanan Holistik Di Gereja Kemah Injil Indonesia Jemaat Yegar Sahaduta Jayapura. Jurnal Jaffray, 12(2). https://doi.org/10.25278/jj71.v12i2.19

Brake, A. (2014). Spritual Formation. Kalam Hidup.

C., J. (1999). Kepemimpinan Kristen Yang Mengubahkan. Andi.

Canada, D. (2005). Spritual Leadership. Gandum Mas.

Channing, N. (2002). Anugerah Dalam Pelayanan Penggembalaan. Veritas: Jurnal Teologi Dan Pelayanan, 3(2), 193-198.

Ginting, C. F. (2018). Konsep Kepemimpinan Penggembalaan Berdasarkan 1 Timotius dan Aplikasinya Terhadap Pertumbuhan Rohani Jemaat. PNEUSTOS: Jurnal Teologi Pantekosta, 1(1). http://sttpantekostasumutaceh.ac.id/e-journal/index.php/pneustos

Hannas, H., \& Rinawaty, R. (2019). Kepemimpinan Hamba Tuhan Menurut Matius 20:25-28. Evangelikal: Jurnal Teologi Injili Dan Pembinaan Warga Jemaat, 3(2), 208-224.

Harming, H., \& Katarina, K. (2019). Strategi Pelayanan Lintas Budaya Berdasarkan Markus 4:1-34. Evangelikal: Jurnal Teologi Injili Dan Pembinaan Warga Jemaat, 3(1), 113-121.

Henry, M. (2011). Tafsiran Matthew Henry-Aplikasi di Google Play. https:// play.google.com/store/apps/details?id=org.sabda.tmh\&hl=in

Holdaway, D. (2001). Kehidupan Yesus. Sinode GKMI. 
Johannes, C., \& Tambahani, B. (2014, July 22). Arti Sebuah Pelayanan. Arti Sebuah Pelayanan. http://suarainjil.com/wp/2014/07/22/arti-sebuahpelayanan/

Karrang, A. (2020). Implementasi Kepemimpinan Yesus Dalam Kaum Milenial Dalam Ppgt. https://doi.org/10.31219/osf.io/t7gn9

Katarina, K., \& Siswanto, K. (2018). Keteladanan Kepemimpinan Yesus Dan Implikasinya Bagi Kepemimpinan Gereja Pada Masa Kini. Evangelikal: Jurnal Teologi Injili dan Pembinaan Warga Jemaat, 2(2), 87-98.

Laks, S. (2007). Tafsir injil Markus. Kanisisus.

Maedjaja, D. (2018). Prinsip-Prinsip Dasar Kepemimpinan Kristen.

Marianti, M. M. (2013). Seperti Apakah Ciri-Ciri Pemimpin yang Melayani? Universitas Katolik Parahyangan.

Maxwell, J. (1995). Mengembangkan Kepemimpinan dalam Diri Anda. Bina Rupa.

Mensah, G. O. (2005). Dicari Pemimpin Yang Menjadi Pelayan. Yayasan Komunikasi Bina Kasih/OMF).

Nelson, A. E. (2002). Sprituality And Leadership. Kalam Hidup.

Pasande, P. (2019). Dicari Dan Mencari Pemimpin Kristen 'Belajar Dari Yesus' [Preprint]. AgriXiv. https://doi.org/10.31220/osf.io/w4pzr

Pengertian Pelayanan: Apa itu Pelayanan? (2014, August 12). Pengertian Ahli. https:/ / pengertianahli.id/2014/08/ pengertian-pelayanan-apa-itupelayanan.html

Pigai, F. (n.d.). Analisis Ciri Kepemimpinan Hamba Serta Relevansinya Pada Masa Kini Berdasarkan Injil Matius 20:26-28. 23.

Plueddemann, J. E. (2009). Leading Across Cultures. Literatur SAAT.

Ronda, D. (2016). Leadership Wisdom: Antologi Hikmat Kepemimpinan, edisi kedua. Kalam Hidup.

Ronda, D. (2019). Kepemimpinan Kristen Di Era Disrupsi Teknologi. Evangelikal: Jurnal Teologi Injili dan Pembinaan Warga Jemaat, 3(1), 1-8.

Sabda 5.1. (n.d.).

Sidjabat, B. S. (2017). Mengajar Secara Profesional. Kalam Hidup.

Sihombing, L. (2015). Isu Etika Sosial Dalam Gereja Yang Mula-Mula. Jurnal Amanat Agung, 11(1), 169-180.

Simanjuntak, A. (1976). Tafsiran Alkitab Masa Kini; Matius-Wahyu. Yayasan Komunikasi Bina Kasih/OMF. 
Sugono, D. (2014). Kamus Besar Bahasa Indonesia (4th ed.). Balai Pustaka \& Gramedia.

Tafsiran Alkitab Matthew Hendry (Version 1.6). (2011). [Indonesia]. Momentum. http://tafsiranalkitabmatthewhendry.org

Tari, E. (2019). Penerapan Pola Pelayanan Yesus [Preprint]. AgriXIV. https://doi.org/10.31220/osf.io/8jxnw

Tenney, M. C. (2013). Survei Perjanjian Baru. Gandum Mas.

Tjhong, P. D. (n.d.). Memimpin Seperti Yesus Memimpin Berdasarkan Matius 20:2528. 42.

Tomatala, Y. (2002). Kepemimpinan Yang Dinamis. YT Leadership Foundation dan Gandum Mas.

Tong, S. (1991). Siapakah Kristus? (Surabaya: Momentum, 1991).45. Momentum.

Warren, R. (2013). The Purpose Driven Life. Immanuel.

Winarto, D. (2019). Pemimpin yang Melayani Menurut Kisah Para Rasul 6-13. 2(1), 7.

Yeakley, T. (2013). Character Formation For Leaders. Kalam Hidup. 